\title{
Discursive archaeology: constituting knowledge of militant nurses in trade associations
}

Arqueologia discursiva: os saberes constitutivos de enfermeiras militantes em entidades de classe Arqueología del discurso: los saberes constitutivos de enfermeras militantes en entidades de clase

\section{Deybson Borba de Almeida', Gilberto Tadeu Reis da Silva', Genival Fernandes de Freitas", Maria Itayra Padilha'"', Igor Ferreira Borba de Almeida' \\ ' Federal University of Bahia. Salvador, Bahia, Brazil. \\ " University of São Paulo, School of Nursing. São Paulo, Brazil. \\ I"' Federal University of Santa Catarina, Center of Health Sciences. Florianópolis, Santa Catarina, Brazil.}

How to cite this article:

Almeida DB, Silva GTR, Freitas GF, Padilha MI, Almeida IFB. Discursive archaeology:

constituting knowledge of militant nurses in trade associations. Rev Bras Enferm [Internet]. 2018;71(3):1128-34.

DOI: http://dx.doi.org/10.1590/0034-7167-2017-0277

Submission: 05-08-2017 Approval: 06-07-2017

\begin{abstract}
Objective: To analyze the constituting knowledge of militant nurses in trade associations. Method: Historical research, based on the oral history method, with a qualitative approach carried out with 11 nurses who are/were militants for professional issues since the 1980s in the state of Bahia. The data collected through semi-structured interviews were organized in the software n-vivo 10 and analyzed based on dialectical hermeneutics. Results: We identified pedagogical, administrative, public health, sociological, and trade union background knowledge as constituent of militant individuals. Final considerations: The constituting knowledge of militant nurses are inscribed in the Social Sciences, distanced from biomedical knowledge and power, pointing at ways for structuring nursing curricula. We identified the Brazilian Association of Nursing as a space for political formation.
\end{abstract}

Descriptors: Nursing; Politics; Leadership; History of Nursing; Nurses.

\section{RESUMO}

Objetivo: Analisar os saberes constitutivos de enfermeiras militantes em entidades de classe. Método: Pesquisa histórica, baseada no método de história oral, de abordagem qualitativa realizada com 11 enfermeiras que militaram/militam pelas questões profissionais desde a década de 1980 no estado da Bahia. Os dados coletados por meio de entrevistas semiestruturadas foram organizados no software n-vivo 10 e analisados com base na hermenêutica dialética. Resultados: Identificados os saberes pedagógico, administrativo, saúde coletiva, sociológico e de formação sindical como saberes constitutivos de sujeitos militantes. Considerações finais: Os saberes constitutivos de enfermeiras militantes estão inscritos nas Ciências Sociais, distanciados do saber e do poder biomédico, apontando caminhos para estruturação dos currículos de enfermagem. Identificou-se a Associação Brasileira de Enfermagem como um espaço de formação política.

Descritores: Enfermagem; Política; Liderança; História da Enfermagem; Enfermeiras.

\section{RESUMEN}

Objetivo: Analizar los saberes constitutivos de enfermeras militantes en entidades de clase. Método: Investigación histórica, basada en el método de historia oral, de enfoque cualitativo realizada con 11 enfermeras que militaron o militan por las cuestiones profesionales desde la década de 1980 en el estado de Bahía. Los datos recogidos mediante entrevistas semiestructuradas se organizaron en el programa informático n-vivo 10 y se analizaron con base en la hermenéutica dialéctica. Resultados: Se identificaron los saberes pedagógicos, administrativos, de salud colectiva, sociológicos y de formación sindical como saberes constitutivos de sujetos militantes. Consideraciones finales: Los saberes constitutivos de enfermeras militantes están inscritos en 
las Ciencias Sociales, alejados del saber y del poder biomédico, señalando caminos para la estructuración de los currículos de enfermería. Se identificó a la Asociación Brasileña de Enfermería como un espacio de formación política.

Descriptores: Enfermería; Política; Liderazgo; Historia de la Enfermería; Enfermeras.

\section{CORRESPONDING AUTHOR Deybson Borba de Almeida E-mail: deybsonborba@yahoo.com.br}

\section{INTRODUCTION}

In Brazil, studies on militant engagement are recent and incipient, the majority being research developed in the late 1990s, from the areas of Education and Social Sciences. This gap represents a fragility to outline a detailed panorama on the theme of political engagement in nursing in Brazil ${ }^{(1)}$.

We understand militancy as a form of engaged and critical political participation, by means of which actions to promote the population's awareness are developed. When exercising it, the aim is to develop new values that enable people to get organized and fight for the construction of a just, dignified, and democratic society ${ }^{(2)}$.

In the area of Health, militancy is expressed in the possibility of meeting between workers, managers, and users, in times of health prevention and promotion, for the production of life, the invention of the self and the world, emerging from the multitude of assemblages that may signal to something that goes beyond the production of health ${ }^{(3)}$.

In the area of nursing in particular, political militancy is understood as an essential aspect to promote changes, in view of an integral, committed, ethical, political, and social approach regarding the human being and the Brazilian society ${ }^{(4)}$.

While it can be understood that this area maintains a close relationship with the subject of politics and social processes, nursing is strongly impregnated by the technical and social division of labor, both in the vertical and horizontal perspectives, due to sociopolitical issues. Such questions, in their turn, result from controversial situations that emerge on a daily basis between physicians and nurses, nurses and patients, nurses and technicians or nursing assistants, and technicians and assistants among each other ${ }^{(5)}$.

However, several studies record the political fragility of nursing, as well as difficulties on the part of the nurses to recognize the political dimension of their profession and practice, in addition to ignorance of their trade associations and council, showing punctual and atypical participation in them ${ }^{(6-9)}$.

On the other hand, despite the changes in the educational and pedagogical areas concerning curricular innovations and of the reforms in the curriculum, the hegemonic model of education in Nursing is still centered on traditional molds, often tied to a biologicist, physician-centered, and technical model. With this, the image of the militant, in many contexts, is considered as inappropriate and inconvenient.

In addition to this background, we can add the fact that when searching the Virtual Health Library (BVS - Biblioteca Virtual em Saúde) for Political Militancy entries, despite its nonexistence as a descriptor, we were able to find 53 studies, but when adding the term Nursing, only one study was found (related to the student movement) and, yet, when adding the word Nurse, we were unable to find any studies. The same occurred when employing the terms political engagement and activism.

These findings can express a knowledge gap when analyzing engagement, militancy, and activism in the profession. However, we believe that the use of different keywords, or, descriptors, by the authors of studies on this subject might hinder the search.

Otherwise, when we searched the scientific literature on the history of Nursing in Brazil, we found two studies, one of them covering the period from 1972 to 2004, among theses and dissertations, and the other, discussing the articles published in the period from 1999 to 2009. We identified 12 theses and dissertations and 30 published scientific articles on trade associations of Nursing ${ }^{(10-11)}$.

This is related with the affirmation that in many spaces a tradition of obedient exercise prevails among nurses, initially guided by religious issues, compatible with the stereotype of a competent professional. Finally, it is evident that obedience can be something taught, learned, and cultivated ${ }^{(12)}$. However, on the other hand, we were also able to observe a movement of resistance to this historically built status quo, countersigned by the social movements, headed by the Brazilian Association of Nursing (ABEn), especially from the 1980s, with the so-called Participation Movement and the Brazilian Political Opening Movement after 20 years of dictatorship ${ }^{(13)}$.

Given the exposed, we defined the following guiding question for this study: Which knowledge constitutes a militant nurse?

To answer that question, we adopted the theoretical and philosophical basis of Michel Foucault, which considers that archaeology focuses on precise historical cutouts to describe not only the manner in which different local knowledge are determined, based on the construction of new objects created in a given time, but also how they correspond to each other and are described in a horizontal manner across a consistent epistemic setting ${ }^{(14)}$. Within the archaeology is the idea of ark, centered in the conception of objects of knowledge, and the concept of archive, based on the recording of these objects. Therefore, it is important to make a horizontal reading of the discourses through the vertical analysis, directed to the present of the historical determinations of our own discourse system ${ }^{(14)}$.

Specifically, on Foucauldian archaeology, discourses are considered regarding their positivity as "facts". It is not about seeking their source or secret meanings, but their emergency conditions, the rules governing their appearance, functioning, changes, and demise, in a given time, as well as the new rules governing the formation of new discourses. All these notes contribute to understand the constitution of militant individuals based on their discourses, on the identification of a temporality, and on horizontal analysis in the construction of discursivities and on the identification of different knowledge.

Thus, this article aims to analyze the constituting knowledge of militant nurses from the $1980 \mathrm{~s}^{(1)}$. 


\section{OBJECTIVE}

To point out that this study is a possibility for the analysis of formative processes in nursing, since the constitution of political individuals correspond to two of the four pillars of the training in nursing.

\section{METHOD}

\section{Ethical aspects}

The study was approved by the Research Ethics Committee of the Federal University of Bahia/School of Nursing, as it observed all the ethical precepts. The anonymity of all participants and confidentiality of the information was respected. The participants signed an informed consent form, in two copies, one for the participant and another for the researcher, after approval by the Research Ethics Committee (REC).

\section{Theoretical-methodological framework}

This is a study that adopted a Foucauldian philosophical theoretical reference, with an understanding approach specifically to dialectical hermeneutics.

\section{Type of study}

Historical research, based on the oral history method, with a qualitative approach.

\section{Methodological procedures}

The data were collected through semi-structured interviews with 11 militant nurses. Five of them had once been Presidents of ABEn and of the Nursing Union in the state of Bahia; and six were active militants, socially recognized as such, but did not acted as presidents for the nursing organizational trade associations.

It is considered that, in the snowball technique, the first participants contacted during application of the research are the "seeds", which were the Presidents of the Union and of ABEn, with positions taken from the late 1980s. These indicated the children of the "seeds", nurses who performed professional militancy in a socially recognized way, according to some criteria: being a nurse; being a militant specifically for issues related to the profession, as well as for the professional appreciation, respect, visibility, and recognition, for a period of at least one year, in a systematic, regular, and socially recognized way, since the 1980s; and participate in social and public movements and mobilizations in nursing.

The limit of five contact attempts to schedule the interviews was defined as the exclusion criterion. After this period, the militant was excluded from the sample, which occurred with two of them. In the other cases, data collection was suspended when data saturation occurred. From the 11 participants, five nurses occupied the post of Presidents at ABEn-Bahia or SEEB in the period researched and six participants were indicated by the snowball technique. In the original version of this article, in Portuguese, we adopted the term "enfermeiras" (female nurses) as the collective form, since only one of the participants was male - a situation that does not occur in the English version, as the term "nurse" does not indicate gender.

\section{Study scenario}

The state of Bahia, in Northeastern Brazil, has an area of $564,733.081 \mathrm{~km}^{2}$ and is the fifth largest Brazilian state regarding extension. The estimated population in 2015 corresponds to $15,203,934$ inhabitants $^{(15)}$. In consultation with the Regional Council of Nursing, Bahia Section,(2014) we confirmed the existence of 17,000 nursing assistants, 60,220 nursing technicians, and 27,447 nurses, totaling 104,667 professionals on the area ${ }^{(16)}$.

\section{Data collection and organization}

After telephone contact and prior scheduling, interviews with the presidents of the associations and the seed children occurred individually in a private environment, conducted by a trained and qualified professional, having an average duration of 2 hours and 55 minutes. The data were collected between July and December 2015. A script was used for the interviews, divided into blocks: sociodemographic issues; political militancy in nursing, correlated to the social movements of the researched period; election process of the formal representatives of nursing; and life story of the militant individual. All interviews were recorded on audio and transcribed in full. We used the name Wind Rose (WR) to identify the interviewees, plus the number of the interview.

\section{Data analysis}

To analyze the data, the method of Dialectical Hermeneutics was employed, based on Interpretive Sociology, which contains two key aspects: experience and reconstruction theory. We sought, based on the experience lived by the political militant nurses in the construction of the phenomenon, their understandings of the knowledge that constitute a nurse ${ }^{(17)}$.

From the operational point of view, by analyzing the data collected from the interviews, the following steps were considered:

1. Level of the fundamental determinations that corresponds to the exploratory phase of the investigation. This is the socio-historical context of social groups and constitutes the fundamental theoretical milestone for analysis, in the case of this study, based on Foucault;

2. Ordering of the data that comprises the systematization of all those collected, the life stories of the militants;

3. Classification of data, in which is necessary to understand that they do not exist by themselves, but are constructed in the exercise of questioning them, based on theoretical foundations;

4. Final analysis, moment in which the articulation between the collected data and the theoretical-philosophical reference of the research are established, to substantiate the formulated questions and objectives (18).

In ordering of data step, the software $\mathrm{N}$ vivo 10 for Windows was used to organize the excerpts of the speeches by units of meaning. This software is widely used in qualitative health research, and also in other areas, such as Anthropology, and several countries, such as Australia and the United Kingdom.

After this step, confronting the Foucauldian theoretical-philosophical reference in which this article is inserted with the possibilities mentioned in the n-vivo software, we designed the following chart, developing categories and sub-categories of analysis: 
Chart 1 - Chart of category and subcategories, Bahia, Salvador, Brazil, 2017

\begin{tabular}{|l|l|l|l|l|}
\hline $\begin{array}{l}\text { Analysis category: DISCURSIVE } \\
\text { ARCHAEOLOGY: Constituting } \\
\text { knowledge of militant nurses in } \\
\text { trade associations }\end{array}$ & WR1 & $\ldots$ & WR11 & $\begin{array}{l}\text { Horizontal } \\
\text { Synthesis }\end{array}$ \\
\hline Pedagogical & & & & \\
\hline Political & & & & \\
\hline Public Health & & & & \\
\hline Sociological & & & & \\
\hline Trade Union Background & & & & \\
\hline Vertical Synthesis & & & & \\
\hline
\end{tabular}

Observation: *Adapted(19); WR - Wind Rose

\section{RESULTS}

From the sample of 11 interviewed individuals, we found the following characterization: six were aged between 60 and 69 years; ten were women; five were single; four had graduated in Nursing 40 to 49 years ago; nine graduated in public universities; six had completed specialization courses; four acted as militants for 40 to 49 years; and income was between 10 and 15 Brazilian minimum monthly wages for four of them.

In the empirical data the knowledge that constitutes the militant individual is visible, as it can be seen in Chart 2.

Chart 2 - Discursive archaeology: constituting knowledge of militant nurses, Bahia, Salvador, Brazil, 2017

Corpus

Dialectical hermeneutics synthesis

[...] [Being a teacher], this requires at least thinking about what role you are exerting there on training [...]. (Wind Rose 1) Pedagogical knowledge

[...] I have a much greater tendency to the administrative area [...] in the School of Nursing I worked in all the positions [...]. (Wind Rose 1)

Administrative knowledge

[...] this activity of mine of giving, of discussing with people very superior to me administratively [...] made me not give in [...]. (Wind Rose 1)

[...] What I have found is that when the student plays a militant role in the student movement [...] later when they enter the world of work, even if they are not in trade associations, they become work militants. Professors can also inspire, have the potential to arouse critical social reflection, but my experience has revealed that there are few of them. Most do not motivate political militancy and even contribute to its obstruction. [...] I want to declare that being a nurse was and is very important for my personal life. I have learned a lot with my relationships with nursing technicians, assistants, and other nurses, and even with the users of health services. [...] (Wind Rose 9)

[...] every human action is political, every being is a political being [...] when I define the theme of a conference I have a political definition, the council has a policy of supervision, I may have a coercive or educational policy [...] we are much more advanced in critical and political position terms than the American nurses, they developed their technical expertise much considering the issue of care of these things. [...] one would say: "discussing with Latin America is more difficult than with European countries and African countries, you are very critical." [...] A political militant, in terms of you being an articulator, negotiator, you have to learn strategies and tactics. [...] (Wind Rose 10)

[...] We made several articulations in the Department of Health [...] [talking on the construction of a primary healthcare unity by the community] women were leading, we held bazaars, sold things to improve, to tow, to paint [the health unit], that was a work of immense learning for me. From the political and technical point of view [...] the largest training school was ABEn. [...] two things for me have been fundamental in terms of my training, from the moment I started to study gender and better understand by this perspective of life in society and the militancy of the Brazilian Association of Nursing, because this made me have another vision of the world, of life, of my space as a teacher, all this gave me a very large amplitude [...] brought me back as a person, as a citizen, as a health care professional, as a teacher, as a woman [...]. (Wind Rose 11)

[...] the process of decentralization of health actions was what allowed this whole country to have nurses occupying positions of Health Secretaries, coordination of projects [...] there was the possibility of appearance of more active nurses and also the magnification of the understanding of public health [...]. (Wind Rose 10)

[...] experience of thinking about a new model of care [...] in the discipline of rural health [...] but we had a whole discussion on this model of care that only existed through campaigns, things that ... Of decentralizations [...]. (Wind Rose 11)

[...] the $8^{\text {th }}$ National Conference on Health that, as we know, was a milestone in the fight for change of the model for health care in the country [...] was the conquest of a Brazilian health reform movement: a political movement that had as actors: workers and users of the health system and that boosted the creation of the Unified Health System. [...] Nursing militants work for the life of the people, therefore, for their right to full life, with dignity. You cannot think of life with dignity without thinking about the right to work, to income, to housing, the right to food. [...] These broad social issues are extremely linked to our field of work as workers of health and as citizens [...]. (Wind Rose 9)

Political

knowledge
Public Health knowledge 


\begin{tabular}{|c|c|}
\hline Corpus & $\begin{array}{l}\text { Dialectical } \\
\text { hermeneutics } \\
\text { synthesis }\end{array}$ \\
\hline $\begin{array}{l}\text { [...] If you ask me, for example, what is my profession, I will say: nurse and not "nursing". This is important so that we } \\
\text { do not continue to contribute with invisibility of the fact that this is a field of work divided technically and socially to } \\
\text { meet the capitalist mode of production and, therefore, organized to satisfy the capitalist mode of production, exploiting } \\
\text { the workforce to make spin the wheel of fortune and concentrate income in small groups [...] and a field [...] which } \\
\text { is complex and subjected to conflicts between the categories of workers and employees. [...] as workers, we sell our } \\
\text { workforce to employers, who understand in our technical division, an opportunity to devalue this work economically. } \\
\text { [...] the fight for rights and humanization is essential, for social justice, the struggle of workers in general. After all, we } \\
\text { are workers [...]. (Wind Rose 9) }\end{array}$ & \multirow{3}{*}{$\begin{array}{l}\text { Sociological } \\
\text { knowledge }\end{array}$} \\
\hline $\begin{array}{l}{[\ldots] \text { I think the issue of training is a serious one, very serious one, one of the things we have done here [...] bringing }} \\
\text { the discussion in the case of the discipline of Sociology Applied to Nursing [...] I fought hard for the presence of this } \\
\text { discipline [...] it featured a discussion of gender, discussion of social issues [...] race [...] of social class. [...] it was a space } \\
\text { where we were doing the training [...]. (Wind Rose 10) }\end{array}$ & \\
\hline $\begin{array}{l}\text { [...] from the moment you incorporate these perspectives in your life [...] race, gender, you cannot look at race, gender, } \\
\text { without looking at issues of social class, [...] you look at the contents not only from the perspective of the technique, but } \\
\text { also of politics, of how this develops and within the processes of health policies[...]. (Wind Rose 11) }\end{array}$ & \\
\hline $\begin{array}{l}{[\ldots] \text { our trade union experience [...] has helped a lot here in the Council to understand where is the role of the trade }} \\
\text { union, and making that connection with the trade union, we work very well articulated with the union in general [...] } \\
\text { from my experience [...] in addition to having taken part of management, I participated in the Union [...]. (Wind Rose 3) }\end{array}$ & $\begin{array}{l}\text { Trade Union } \\
\text { Background }\end{array}$ \\
\hline
\end{tabular}

\section{DISCUSSION}

Based on the analysis of the speeches, aided by the n-vivo software, we were able to identify the following knowledge: pedagogical, administrative, public health, sociological, and trade union background. These results agree with another study that stated that the medical affiliation of nursing and the idealization of the nurse by the scope of the physicians' work interferes in their professional identity ${ }^{(20)}$.

In this sense, distancing from the professional practice of the physician can provide other models of identification, which converges to the findings of this study, in which the highlighted knowledge is marked by unlinked areas, in part, from the medical context $\mathrm{t}^{(20)}$.

The first knowledge that constitutes a militant nursing professional involves the pedagogical field, the ability to think. Acting as a teacher for a long time allowed the participants to reflect more critically and contributed to their responsibility when teaching the profession. Under this perspective, education is a human experience that allows an individual to intervene in the world, which requires, in addition to knowledge of the contents, effort to avoid the mere reproduction of the dominant ideology. More than that, it is necessary to expose it since, due to its own contradictory dialectic, education cannot be just one or the other, of these two things ${ }^{(21)}$.

Another knowledge pointed out as constituting of the militants was the administrative, identified in the hermeneutic analysis as a difference, because when one reflects on the practice of a militant, in particular constituting knowledge, this knowledge does not reveal itself at first. However, it is worth pointing out that the militant practice identified in nursing occurs in institutional representative spaces and, certainly, for this reason, an administrative knowledge is essential.

In addition, it is an important knowledge to those who assume the direction of representative associations, since this activity requires even more transparency, responsibility, and democracy in the use of financial resources, which gives to the managers economical and decision-making power.

Others knowledge identified as constituting of the militant individual was the political. We understand that the political dimension is inherent to individuals, however, in the case of some, the political exercise is more expressive, since they conceive politics as a process by which interests are turned into objectives, and these objectives lead to the formulation and making of effective transformative decisions ${ }^{(22)}$. In this regard, during data analysis, we observed a diverging aspect about the teaching practice, referred to as favorable of the obstruction of militant practice, a characteristic that shall be addressed in a future study.

We also observed, in the speeches of several militants, commitment to the most vulnerable communities, as well as with social issues that permeate the health-disease process. In these cases, they exert, through militancy, the power to intervene on the social reality. The militant practice is seen, therefore, as power generator device, expressed in the relationships, in the forms of resistance against the different forms of power, visible in some of the speeches. We highlight that the resistance acts as a chemical catalyst, to clarify the relationships of power, find its position, and discover its application point and methods used ${ }^{(23)}$.

On the other hand, when looking at the political practice in nursing, we noticed that this militant path, politically involved with the area, does not prevail. On the contrary, a study on ABEn mentions the little knowledge regarding the history of the profession and the importance of the professionals' participation in the Association, as well as the ignorance of the historical trajectory of the entity and the absence of new leadership in power spaces, which reduces the critical sense of discussions ${ }^{(24)}$.

In this sense, we identified a dissension in the speeches, since Brazilian nurses are recognized as critical professionals in the international scenario. Such an explanation is based on a series of findings of this study, such as: the political regime adopted by the 
country and the insertion and contribution of nurses in the Public Health, management of services, and Unified Health System.

Another subcategory found was the knowledge concerning Public Health, here conceived as a field of knowledge production and specialized professional intervention, but also interdisciplinary, in which there is no precise or rigid boundaries between the different ways of listening and looking, thinking, and producing health ${ }^{(25)}$.

In some of the speeches, it is possible to notice that the knowledge more distanced from the medical practice, from the hospitalcentered and biologicist model, compose the militants' repertory. This results in practical possibilities of liberation and construction of libertarian knowledge of submission, invisibility, and lack of identity in all the categories that constitute the nursing staff.

Public Health knowledge contributes to significant advances in nurses' intervention, as it enables them to expand the health practices and devise public health beyond positivism and structuralism. It also allows nurses to transcend the current public health model, made in the image and likeness of the technoscience and biomedical model ${ }^{(26)}$.

Likewise, sociological knowledge is pointed out as constitutive of militant nurses, here characterized as a science, whose object is the study of social phenomena linked to the health-disease process. It is a knowledge that requires collective and social approaches of the disease and training of a specialized staff to understand this perspective $\mathrm{e}^{(27)}$.

The empirical data evidence how the curricular component on health sociology adds to nursing, expanding the role of the nurse to the understanding of social issues, as well as on the various aspects that influence the health-disease process. In addition, other discourses indicate that the sociological perspective corroborates to the understanding of race and gender issues, which also affect the work of nurses and nursing team and influence the process of illness.

This discussion is aided by a study that deals with the experience of teaching of Sociology Applied to Nursing as a means of equipping future workers to face the world of work, having as guiding axis the nursing work. In this case, Sociology is used as a tool for analyzing nursing, which focuses on the work as an educational principle and knowledge as a liberation for nurses ${ }^{(28)}$.

In the last subcategory, the trade union background knowledge was mentioned in the constitution of militants, due to the intrinsic relationship between the class struggle and the establishment of trade unions in Brazil for the confrontation of conflicts between exploiters and exploited, and the biases of existing power in the disputes of society ${ }^{(28)}$.

Finally, we highlight that the speech of one of the interviewed, the last one highlighted in Chart 2, punctuates the association and the nursing union as spaces of constitution of political militants, as they represent the entire exercise and professional practice of nursing: the theoretical development, the protection of their interests, and the regulation of their exercise ${ }^{(4)}$.

On the other hand, it is recognized that qualitative and historical studies have aspects that limit the generalization of the results. However, the findings corroborate the literature review on the topic, while presenting innovative and unknown aspects for the field.

\section{FINAL CONSIDERATIONS}

The constituting knowledge of militant nurses are inscribed among the Social Sciences, distanced from Medicine, especially the pedagogical, political, sociological, public health, and trade union background knowledge. We identified the Brazilian Association of Nursing as an important space for political formation.

It is valid to point out that this study is a possibility of analysis of the formative processes in nursing, since the constitution of political individuals corresponds to two of the four pillars of training: knowing how to live together and to be, despite the fragility of the political dimension of training and of the highlighted context determinants. In this possibility is the centrality of the emancipatory knowledge on the training of professionals in this area, being important to point out that training does not occur only at school, it is developed in the course of life. In addition, emancipatory knowledge is made possible by different types of knowledge, practices, and experiences that activate the condition of being an individual.

In conclusion, this study presents a theoretical, philosophical, and methodological basis that enables its replication in other parts of the world. The author, by participating in a research group in Portugal, when implementing a research that dealt with the life story of militant nurses, found very similar results on the European continent.

\section{FUNDING}

This study was funded by the Coordination for the Improvement of Higher Education Personnel Foundation (CAPES) by granting a scholarship for the Doctoral Sandwich Program Abroad.

\section{REFERENCES}

1. Modalidades de intervenção política no Rio Grande do Sul [Tese]. Porto Alegre: Universidade Federal Rio Grande do Sul; 2007.

2. Baltazar B. Encontros e desencontros da militância na vida cotidiana. Psic: Teor Pesq [Internet]. 2004 [cited 2016 Apr 4];20(2):18390. Available from: http://www.scielo.br/pdf/ptp/v20n2/a11v20n2.pdf

3. Oliveira GN, Pena RS, Amorim SC, Carvalho SR, Azevedo BMS, Martins ALB, et al. Novos possíveis para a militância no campo da Saúde: a afirmação de desvios nos encontros entre trabalhadores, gestores e usuários do SUS. Interface Comunic Saúde Educ [Internet]. 2009[cited 2016 Apr 4];13(supl.1):523-9. Available from: http://www.scielo.br/pdf/icse/v13s1/a05v13s1.pdf

4. Geovanini T. História da Enfermagem: versões e interpretações. 3. ed, Rio de Janeiro: Revinter; 2010. 
5. Braverman H. Trabalho e capital monopolista: a degradação do trabalho no século XX. 4ª Edição. Rio de Janeiro: Jorge Zahar Editores, 1983.

6. Bellaguarda MLR, Padilha MICS, Pires DEP. Regional nursing council of Santa Catarina (1975-1986): importance for the profession. Texto Contexto Enferm [Internet]. 2015[cited 2016 Apr 4];24(3):654-61. Available from: http://www.scielo.br/pdf/ tce/2015nahead/0104-0707-tce-2015003750013.pdf

7. Budó MLD, Beck CLC, Dal Sasso GTM, Gonzales RMB. Responsabilidade coletiva na participação da enfermagem em suas entidades organizativas. Rev Bras Enferm [Internet]. 2001[cited 2016 Apr 4];54(2):237-47. Available from: http://www.scielo.br/ pdf/reben/v54n2/v54n2a09.pdf

8. Almeida DB, Queirós PJP, Silva GTR, Laitano ADC, Almeida SS. Sexist stereotypes in portuguese nursing: a historical study in the period 1935 to 1974. Esc Anna Nery Rev Enferm [Internet]. 2016[cited 2016 Apr 4];20(2):228-35. Available from: http://www. scielo.br/pdf/ean/v20n2/en_1414-8145-ean-20-02-0228.pdf

9. Almeida DB, Silva GTR, Queirós PJP, Freitas GF, Laitano ADC, Almeida SS, et al. Portuguese nursing: history of the life and activism of Maria Augusta Sousa. Rev Esc Enferm USP [Internet]. 2016[cited 2016 Apr 4];50(3):495-501. Available from: http:// www.scielo.br/pdf/reeusp/v50n3/0080-6234-reeusp-50-03-0498.pdf

10. Padilha MICS, Kletemberg DF, Gregório VRP, Borges LM, Borenstein MS. A produção da pesquisa histórica vinculada aos programas de pós-graduação no Brasil, 1972 a 2004. Texto Contexto Enferm [Internet]. 2007[cited 2016 Apr 4];16(4):617-9. Available from: http://www.scielo.br/pdf/tce/v16n4/a11v16n4.pdf

11. Padilha MICS, Ferreira AC, Maliska ICA, Villarinho MV, Zytkuewisz GV, Sell C. Tendências recentes da produção em história da enfermagem no Brasil. Hist Cienc Saúde-Manguinhos [Internet]. 2013[cited 2016 Apr 4];20(2):695-707. Available from: http:// www.scielo.br/pdf/hcsm/v20n2/0104-5970-hcsm-20-02-00695.pdf

12. Passos E. De anjos a Mulheres: ideologias e valores na formação de enfermeiras. 2. ${ }^{a}$ Ed. Salvador: EDUFBA, 2012.

13. Albuquerque GL. O Movimento Participação na Associação Brasileira de Enfermagem - Seção Santa Catarina, na visão de suas principais lideranças [Tese]. Florianópolis, SC: Departamento de Enfermagem, UFSC; 2001.

14. Revel J. Dicionário Foucault. Rio de Janeiro: Forense Universitária, 2011.

15. Brasil. Instituto Brasileiro de Geografia e Estatística. IBGE. Censo Demográfico 2009 [Internet]. 2009[cited 2016 Apr 4]. Available from: http://www.sidra.ibge.gov.br/

16. Conselho Regional de Enfermagem. Seção Bahia. Consulta ao conselho com relação ao quantitativo de profissionais, Salvador, 2014.

17. Bleicher J. Hermenêutica Contemporânea. Lisboa: edições 70, 1980.

18. Minayo MCS. O Desafio do Conhecimento. São Paulo: Editora Hucitec, 1996.

19. Silva TOS, Nascimento MAA, Alencar BRA. Hermenêutica Dialética: uma experiência enquanto método de análise na pesquisa sobre acesso do usuário à assistência farmacêutica. Rev Bras Prom Saúde [Internet]. 2012[cited 2016 Apr 4];25(2):243-50. Available from: http://periodicos.unifor.br/RBPS/article/view/2236

20. Collière MF. Promover a Vida das práticas das mulheres de virtude aos cuidados de Enfermagem. Coimbra: Lindel; 1999.

21. Freire P. Pedagogia da autonomia: saberes necessários à prática educativa. São Paulo: Paz e Terra, 1996.

22. Ribeiro JU. Política: quem manda, porque manda, como manda. Rio de Janeiro: Editora Nova Fronteira; 1998.

23. Foucault M. Estratégia, Poder-Saber. 3ª Ed. Rio de Janeiro: Forense Universitária; 2012.

24. Oliveira FVS. Associação Brasileira de Enfermagem - mudanças e continuidades: a propósito do movimento participação (19791989) [Dissertação]. Natal (RN): Universidade Federal do Rio Grande do Norte; 1990.

25. Campos GWS. Tratado de Saúde Coletiva. Rio de Janeiro: Fiocruz; São Paulo: Hucitec; 2006.

26. Campos GWS. Saúde pública e saúde coletiva: campo e núcleo de saberes e práticas. Ciênc Saúde Colet [Internet]. 2000[cited 2016 Apr 4];5(2):219-30. Available from: http://www.scielo.br/pdf/csc/v5n2/7093.pdf

27. Alves DB. Trabalho, Educação e Conhecimento na Enfermagem: uma contribuição aos estudos sobre força de trabalho feminina. Salvador: Central; 1997.

28. Rossi W, Gerab W. Para entender os sindicatos no Brasil: uma visão classista. São Paulo: Expressão Popular, 2009. 